Arch. hist. jap. Vol. 19, n. 1 (February 1960).

P. $75-93$.

Anas. Labor. of Prof. H. SETO, Tohoku University, Sendai.

\title{
On Nerve Supply, especially, Sensory Nerve Supply of the Lung in Formosan Macaque.
}

台湾猿の肺の神経特に知覚神経支配に就て。

\section{Kazuo FUKASE 深 瀬 和夫.}

(Received October 5. 1959.)

Many histological studies on the nerve supply of the lung have been reported on since olden days, among which that of HAYASHI (1937) on the human lung has been an epochal and a very reliable one. He succeeded not only in demonstrating for the first time that the terminations of the vegetative nerve fibres are in the form of terminal reticula (STÖHR) in the lung, too, but also in detecting sensory fibres and their terminations therein and thoroughly revealing their formation and structure.

More recently, SAITO, NUMATA and OMOTO made minute studies on the nerve supply of the lungs of dog, bat and goat, respectively, and obtained some very interesting results from the stand-point of comparative histology. It seems of deep significance that they could point out existence of sensory terminations specific in form to these mammals of different orders.

The author of this paper has been specially interested in the subject and chose the lug of Formosan macaque - an animal never thus studied, as far as I am aware - as my material of study, for examination of the innervation, especially, the sensory innervation in it.

The materials were fixed in $10 \%$ neutral formol for a long time, then cut into $40 \mu$ frozen sections, stained by SETO's impregnation method in routine use at this laboratory and minutely examined under a microscope. The findings obtained were then studied in comparison with the results reported by the authors cited above, as described in the following.

\section{Individual Findings.}

The histological structure of the lung of Formosan macarue, as described below, is somewhat different from that in dog (SAITO) and goat (OMOTO), but is rather similar to that of the human lung (HAYASHI). Now, the two extrapulmonary bronchi of ca. $10 \mathrm{~mm}$ in diameter, coming from the bifurcatio tracheae to the lung radices, branch out into intrapulmonary bronchial branches ca. 5-6 $\mathrm{mm}$ in diameter and then gradually into many finer bronchial branches.

The intrapulmonary bronchial branches of largest diameter, as shown in Fig. 1 , is covered by a 3-4-rowed ciliated epithelium containig many goblet cells. Beneath the epithelium, a considerably well-developed basement membrane is found. The propria mucosae consists of a connective tissue rich in fibrocytes and contains 
groups of lymphocytes here and there. Outside the propria, there is a connective tissue submucosa comparatively loose in arrangement and containing smooth muscle

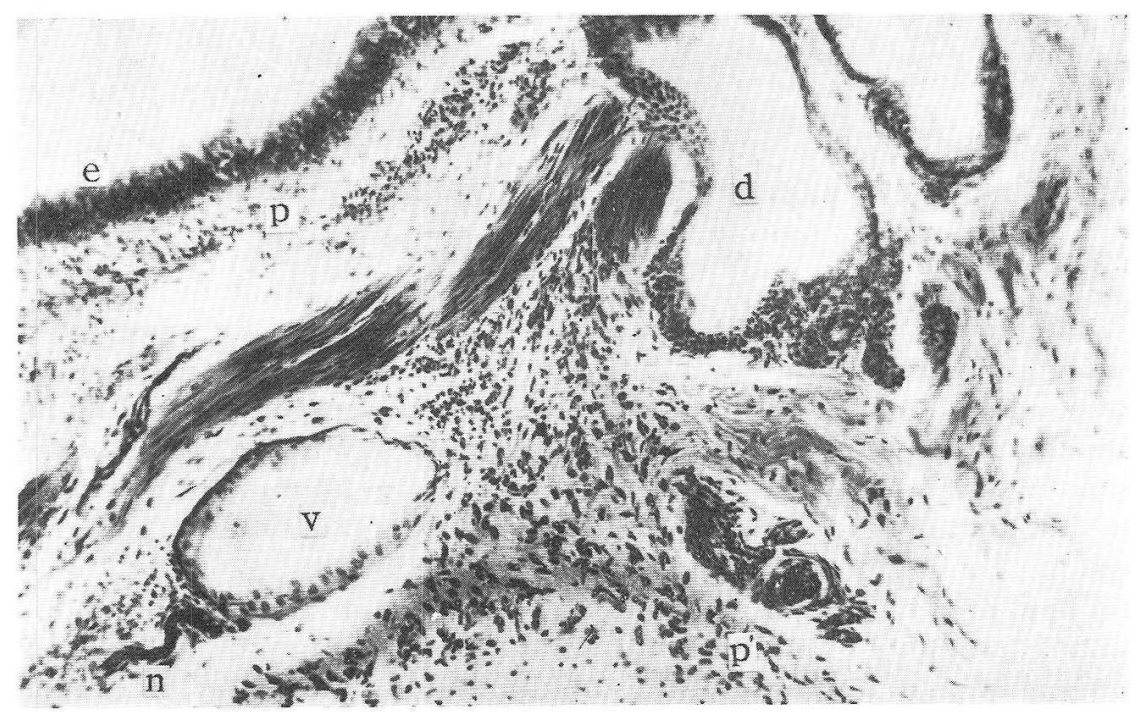

Fig. 1. A cross section of an intrapulmonary bronchial branch of largest diameter of a Formosan macaque. $e$ ciliated epithelium, $p$ propria mucosae, $m s$ mooth muscle layer, $d$ enlarged gland duct, $v$ enlarged vein, $c$ perichondrium, $n$ nerve bundle of the submucosal plexus. Details in the text. SETO's impregnation. Photo $\times 100$.

bundles in some parts. This muscle layer is not a closed tube in form as in goat, but is disjointed into fragments of muscle bundles which run more often circularly but sometimes also obliquely.

Outside the muscle layer exist the bronchial glands. These glands are poorer in development than in man but far better doveloped than in dog or goat. Around the gland layer, cartilaginous pieces of hyaline nature are arranged in one row, as in man, and not in multiple rows, as in dog and goat. This arrangement is covered by a well-developed perichondrium.

The above largest bronchial branches soon pass over into the medium-sized bronchial branches about half in diameter $(2-2.5 \mathrm{~mm})$ by ramification. $\Lambda$ s shown in Figs. 2, 3 and 4, the epithelium in those medium-sized branches is a thinner 2-3rowed ciliated epithelium. The cartilaginous pieces become smaller and rapidly fewer. Accordingly, we expect that well-developed longitudinal mucous folds should be found in the mucous membrane of these bronchial branches, as in man and the other animals above, but it is interesting that such was not the case, the foids being only very poorly developed or sometimes entirely absent. The bronchial glands are also only very scanty here. The muscle layer becomes thinner but more continuous and its muscle bundles most often surround the propria circularly. So, in these medium-sized branches, the muscle tissue alone is better developed than any other tissue.

By further ramification, the above bronchial branches divide into branches of 


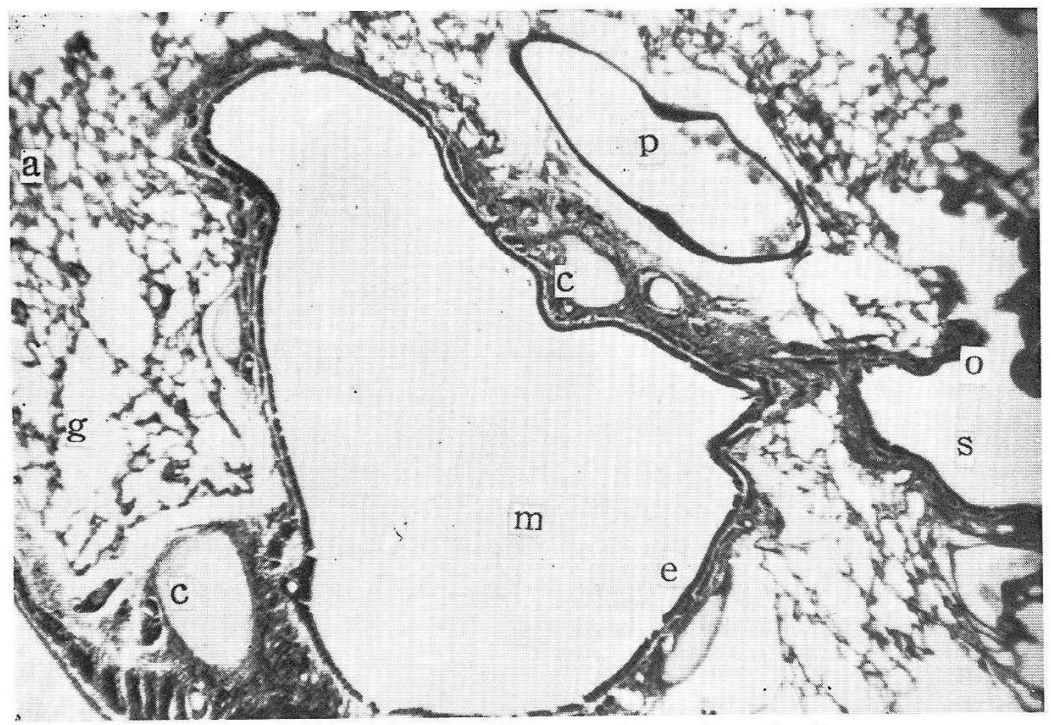

Fig. 2. A cross section of a medium-sized bronchial branch $m$ of a Formosan macaque. e 2-3-rowed ciliated epithelium, $c$ cartilaginous piece, s small-sized bronchial branch, $o$ bronchiolus, $g$ alveolar duct, $a$ alveoli, $p$ a. pulmonalis. Details in the text. Same staining. Photo $\times 24$.

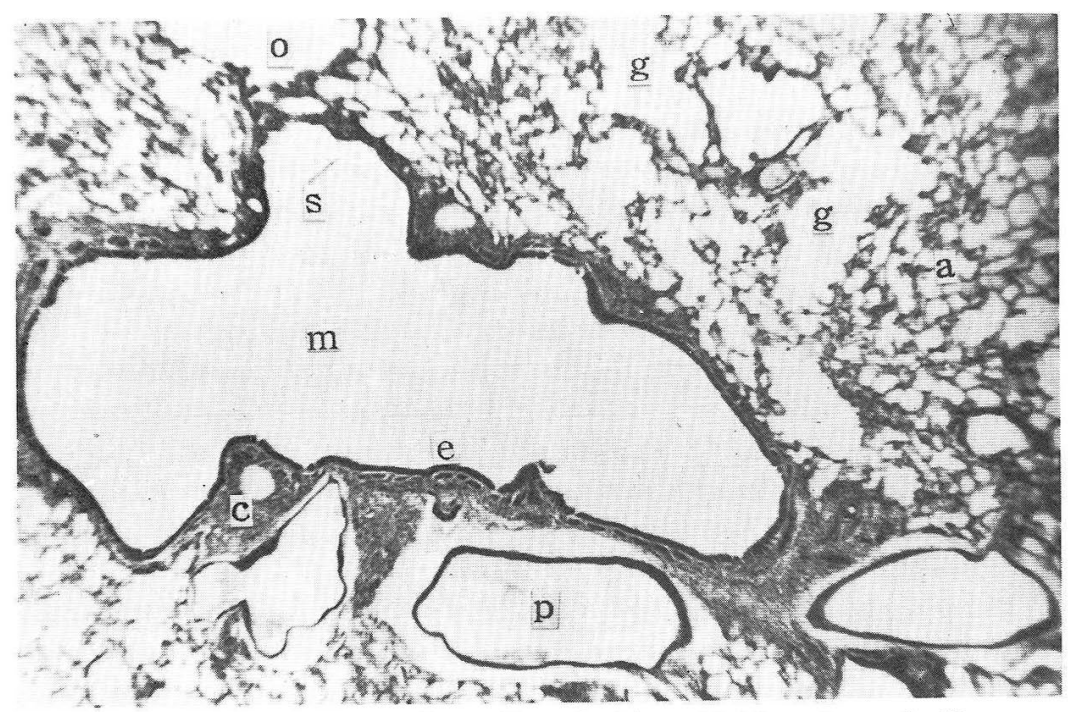

Fig. 3. A longitudinal section of a medium-sized bronchial branch $m$ of a Formosan macaque. Nomenclature is the same as that in Fig. 2. Same staining. Photo $\times 24$.

1-1.5 $\mathrm{mm}$ in diameter (Figs. 2 and 5), the pieces of cartilages become even smaller in number and size, but again, against all anticipation, the formation of longitudinal mucous folds is very poor here, the number of bronchial glands is further reduced. The epithelium is a 2-rowed ciliated one containing a small number of goblet 
cells.

Further ramification reduces these branches into the so-called terminal bronchioli (Figs. 2 and 6), 0.5-0.8 $\mathrm{mm}$ in diameter; here cartilaginous pieces are nearly absent and the epithelium is a 1-rowed ciliated or non-ciliated cylindrical epithelium. A well-developed smooth-muscle layer always running circularly surrounds the very thin propria. In the more distal part of the terminal bronchioli, the epithelium becomes a non-ciliated cubic epithelium and the bronchioli become the so-called bronchioli respiratorii covered by a tubular layer of smooth muscle tissue still in good development. These bronchioli run rather short courses in Formosan macaque before passing over into the alveolar ducts. Some alveoli are formed in the walls of the bronchioli respiratorii, as in man and the other animals above.

The alveolar ducts finally pass over into the alveolar sacs, in the same manner as in man and the other animals cited above. The walls of the alveolar ducts as well as the alveolar sacs consists of alveoli. These are formed of nucleated cubic epithelial cells and large non nucleated flat epithelial cells, their cellular boundary being quite definite. The interalveolar spaces are rich in blood capillaries.

Group of lymphocytes are found in all parts of the walls of the bronchial branches of various size described above, and especially, in the bronchioli, it is of interest that rather large lymph nodes (Fig. 7) are in formation. The media of the a. pulmonalis is of a smooth muscle tissue, as in dog or goat, but never of a heart-muscle tissue, as in bat.

In the human lung, the fundamental or perichondral plexus originating in the plexus pulmonalis anterior et posterior found in the walls of the large bronchial branches is comparatively well developed, containing many a ganglion here and there - of ten enough, large ganglia composed of numerous ganglion cells. In the large bronchial branches of my Formosan macaque, however, the development of the abovementioned nerve plexus is much poorer, the nerve bun tles forming the plexus being rather thin and observable only in a small number sporadically in the fibrous membrane or adventitia containing the cartilaginous pieces. The ganglia are also very few and even the largest of them contain only 15-20 nerve cells.

The submucosal plexus originating in the fundamental plexus and formed in the gland layer or just outside the muscle layer in the large bronchial branches is also very poorly developed (Fig. 1). In particular, in the areas where the muscle tissue or the bronchial glands are very ill developed or absent, no nerve bundles or plexus were found in the submucosa. The proprial plexus in this part war also very poorly developed in my monkey specimens.

The nerve plexus formed in the intrapulmonary bronchial walls contains, besides non-medullated vegetatice fibres, a number of medullated sensory fibres probably originating in the $n$. vagus and, interestingly enough, including a rather large number of enormously thick fibres.

The nerve plexus formed in the large bronchial branches is similarly formed in the smallest bronchial branches as well as in the larger ones, but they become less well developed as the bronchial branches become reduced in size by ramification, the nerve bundles becoming slenderer and the ganglia losing in size. Figs. 4 and 5 show particularly well developed plexus formed outside the muscle layer of two bronchial 


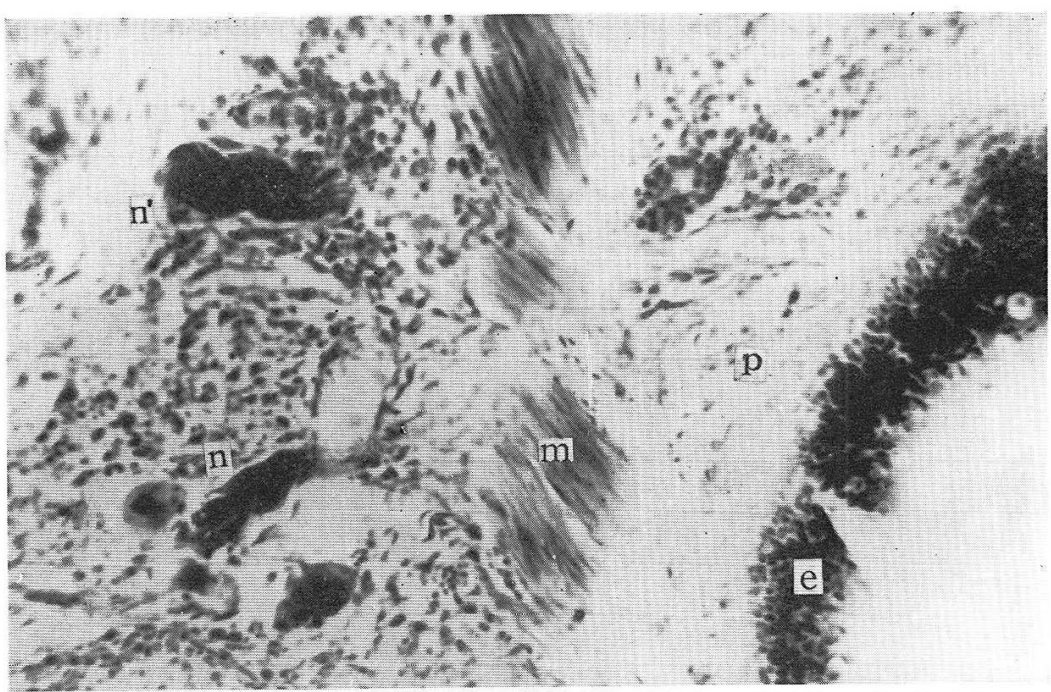

Fig. 4. A rather high magnification of a medium-sized bronchial branch of a Formosan macaque. $e$ ciliated epithelium, $p$ propria, $m$ smooth muscle layer, $n$ nerve bundle of submucosal plexus containing some nerve cells in its vicinity, $n^{\prime}$ another thicker nerve bundle of the plexus. Details in the text. Same staining. Photo $\times 200$.

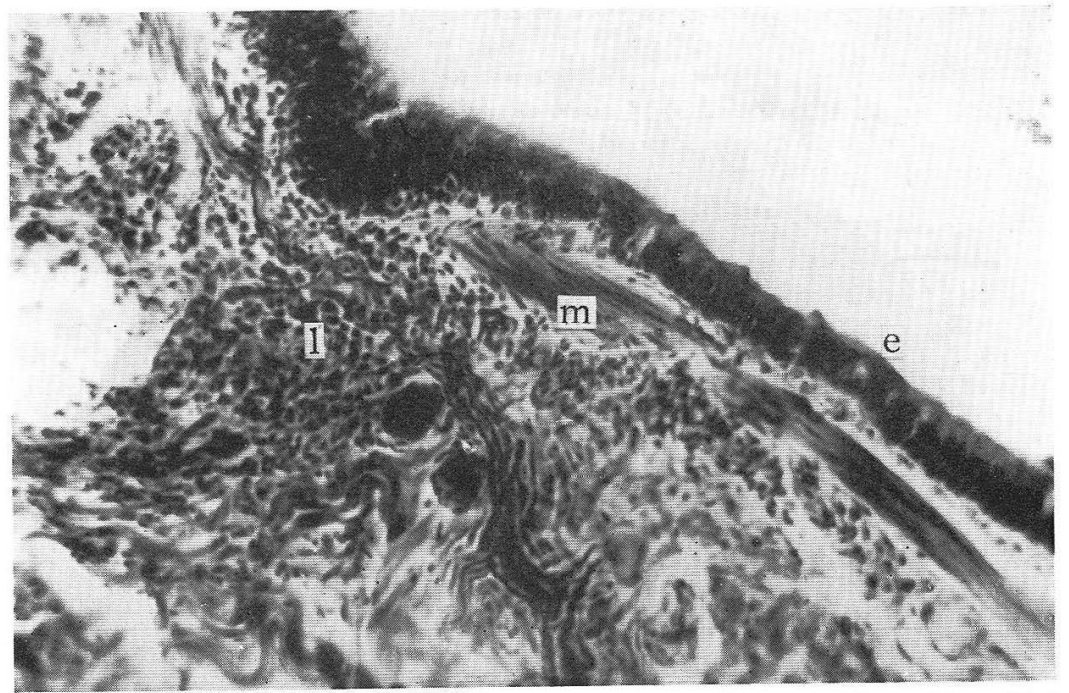

Fig. 5. Nerve plexus accompanied with 2 nerve cells found in a small-sized bronchial branch of a Formosan macapue. $e 2$-rowed ciliated epithelium, $m$ smooth muscle layer, $l$ lymphocytes gathering in the submucosa. Details in the text. Same staining. photo $\times 200$.

branches, $2.5 \mathrm{~mm}$ and $1.5 \mathrm{~mm}$ in diameter, respectively. Both the plexus contain 2-3 ganglion cells.

The ganglion cells in the ganglia, usually having nerve processes and showing 
multipolarity, of course belong to the sympathicus. It is, however, difficult to know whether any of these cells belong to the DOGIEL's Type I or II, as their nerve processes are much less developed than in man or dog. What does this difficulty in the distinction of the sympathetic ganglion cells into the two types morphologically so distinct mean. Perhaps, it shows that the morphological difference does not mean any functional difference.

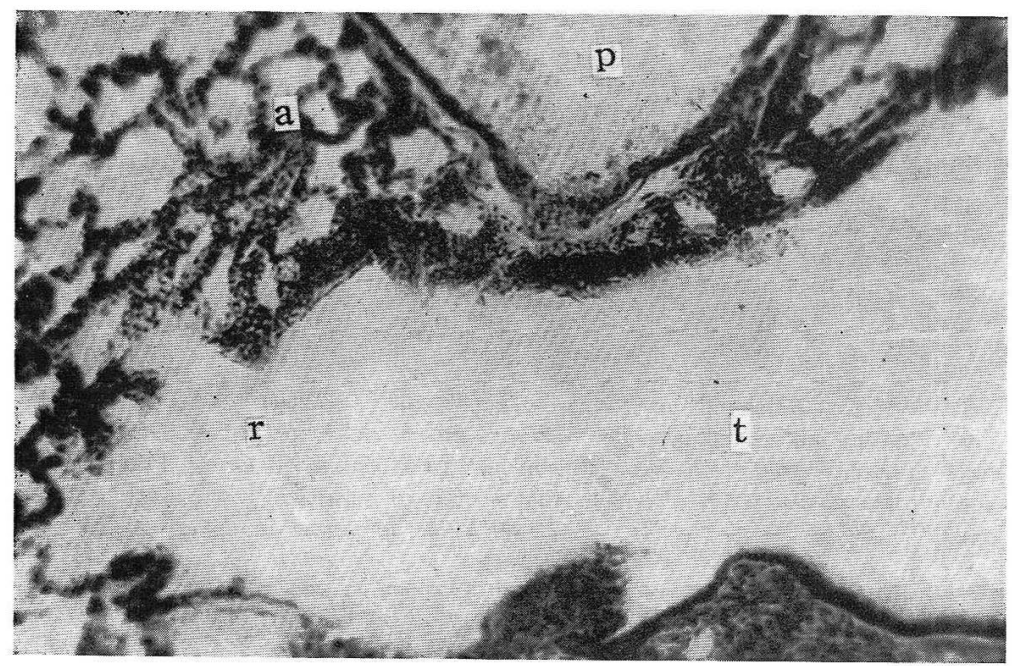

Fig. 6. Bronchiolus terminalis $t$ and bronchiolus respiratorius $r$ of a Formosan macaque. $a$ alveoli, $p$ a. pulmonalis. Details in the text. Photo $\times 100$.

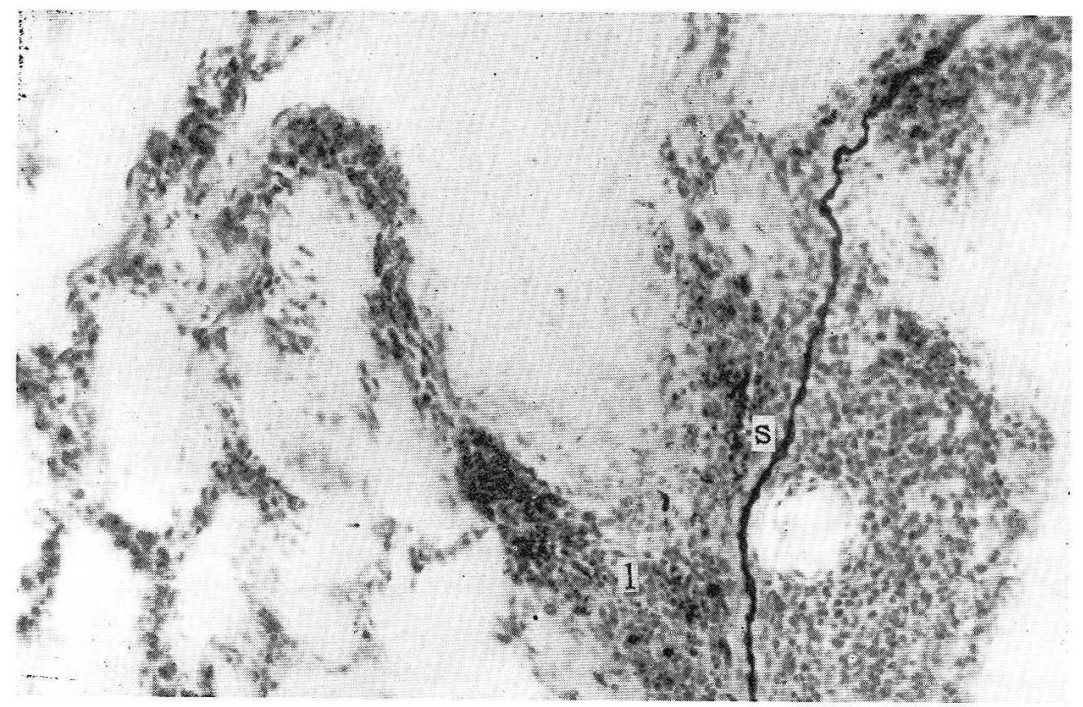

Fig. 7. A thick myelinated sensory fibre $s$ runing through a large lymph node $l$ formed in the wall of a bronchiolus of a Formosan macaque. Same staining. Photo $\times 200$, 
The vegetative fibres, in the bronchial branches, always distribute in the bronchial glands and the smooth-muscle tissue. Their terminations are as always terminal reticula (STÖHR), as demonstrated in all the works at our laboratory, and stand in control by contact over the supplied tissue cells. The details will be omitted here.

It is of deep interest to study utterly reliable works on the sensory innervation of the lungs of man and some other animals in the past literature. For example, in the muscularis of the large bronchial branches of the human lung have been discovered sensory terminations Type I concerned with the blood-pressure falling reflex, constructed somewhat more simply than those in the human trachea (SASAKI), by SUNDER-PLASSMANN and more recently by HAYASHI. SAITO also found such terminations in the dog's bronchial branches. NUMATA found similar terminations in the bronchial branches of bat and more recently OMOTO in the counterparts of goat.

It has been verified that the mucous membrane of the bronchial branches too contain a rather large number of sensory terminations, but in form these were found considerably dissimilar by the kind of animals. E.g., in the human bronchial branches, intraepithelial branched terminations of considerable complexity are rather abundant, while intraepithelial fibres here are very scanty and of the simplest unbranched type in dog; in goat, such fibres are entirely absent, the few sensory fibres coming into the mucous membrane ending in unbranched and simple branched terminations always subepithelially, but in bat, rather complex branched terminations are formed subepithelially as well as intraepithelially in the bronchial branches.

Around the bronchioli and in the alveolar walls of the animals cited above, and in particular, in goat (OMOTO), and bat (NUMATA), many unbranched and simple branched sensory terminations have been discovered. NUMATA has found welldeveloped unbranched sensory terminations in the pleura visceralis of bat, too, but OMOTO, though he found small nerve bundles containing thick sensory fibres running as far as into the pleura of goat, could not make out their terminations in it.

The terminations of sensory fibres I found distributed in the lung of my Formosan macaqee were as described in the following.

In the large bronchial branches of the macaque, the pieces of cartilage are large in size and accordingly the bronchial glands are comparatively few, the smooth muscle tissue is only poorly developed in the intercartilaginous spaces and the mucous membrane is mostly thinly formed on the inside of the cartilage; perhaps due to such a construction, the number of sensory fibres here seems to be samller than in the medium-sized bronchial branches which are completely covered up by a layer of circularly running muscle fibres.

Sensory terminations Type I concerned with the blood-pressure falling reflex are found in the muscle layer of the bronchial walls of Formosan macaque, quite as in the same region of man and the other animals cited above. These terminations, however, are very limited in number in the large bronchial branches, but rather frequent in the medium-sized branches of $2.5-3 \mathrm{~mm}$ in diameter. They are formed by very thick fibres and usually constituted of several branched fibres showing 
distinct change in size. Round or oval special nuclei are found here and there in their terminal area, but in my macaque as well as in any other animals reported on hitherto, no neurofibrillar expansions, as seen in the terminations in the human lung, were ever found. Thus, these terminations in Formosan macaque are far lower in development than those in man and nearly on the same of footing as those in dog and goat.

In the photograph Fig. 8 are shown 2 sensory terminations Type I concerned

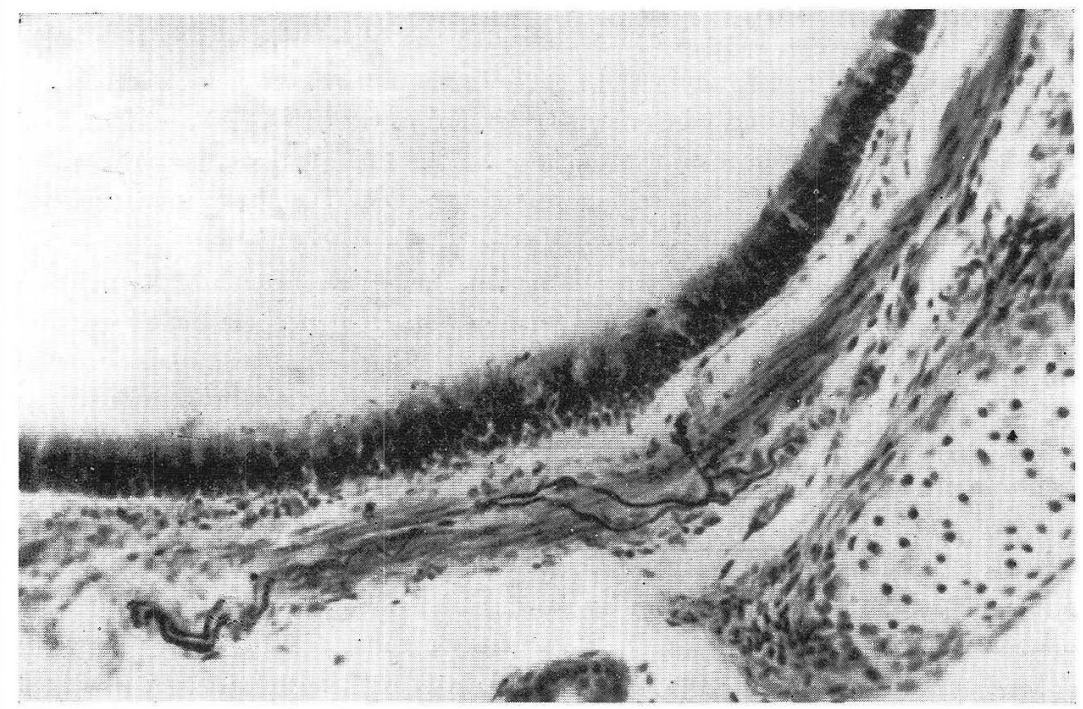

Fig. 8. 2 sensory terminations Type I concerned with the blood pressuref alling reflex found in the muscle layer of a medium-sized bronchial branch of a Formosan macaque. Terminal fibres show perceptible change in size and mostly end bluntly. Details in the text. Same staining. Photo $\times 200$.

with the blood pressure falling reflex formed by 2 very thick sensory fibres running side by side found in a cross-section of a medium-sized bronchial branch. These 2 fibres, after losing their myelin sheath, branch out into several terminal fibres, which run more or less long courses over a rather large area in the muscularis while showing perceptible change in size and end more of ten bluntly than sharply. Fig. 9 shows another sensory tesmination of similar form found in a longitudinal section of a medium sized bronchial branch. Here too, the terminal fibres are about half a dozen in number, show some change in size in their more or less winding courses and end bluntly or sharply in the muscularis. The details on their courses, however, are not shown with adequate distinctness in this photo under high magnification.

Besides the above sensory terminations ending in the muscularis, a considerable number of branched sensory terminations are found subepithelially and intraepithelially in the large and the medium-sized bronchial branches. The intraepithelial terminations here exceed the subepithelial termintions in number. Especially, in the large bronchial branches, the greatest majority of the terminations are of the 


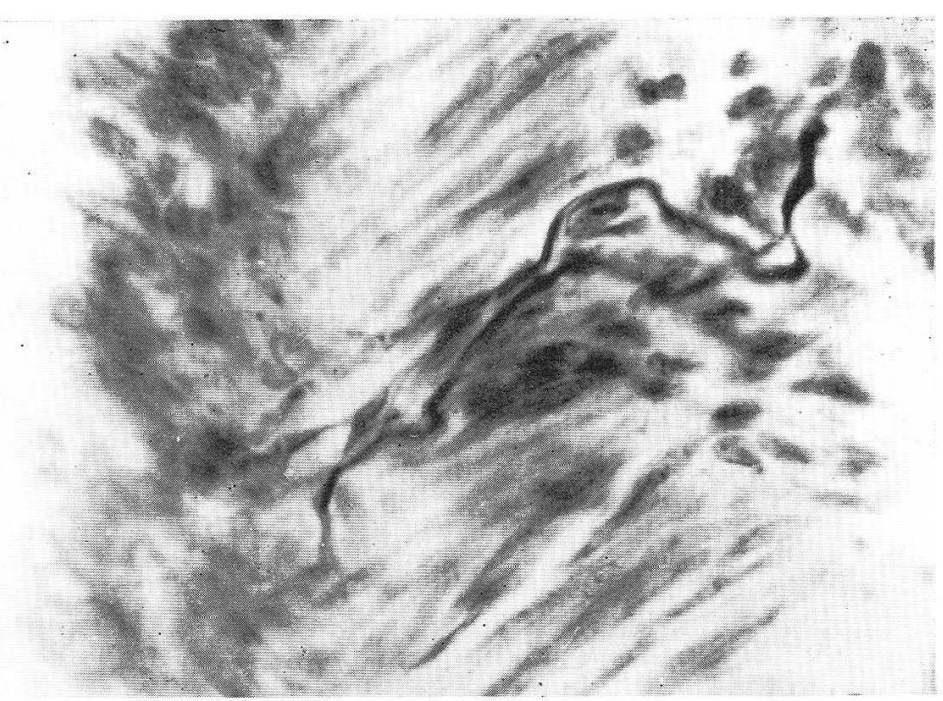

Fig. 9. A sensory termination Type I concerned with the blood pressure falling reflex found in a longitudinal section of a medium-sized bronchial branch of a Formosan macaque. Terminal fibres in the muscle layer are of the same nature as those in Fig. 8. Details in the text. Same staining. Photo $\times 800$.

intraepithelial type.

These terminations mostly are formed by medium-sized sensory fibres, but not rarely by thick fibres. Those in the large bronchial branches are generally more complex in form than those in the medium-sized branches, but some of the latter

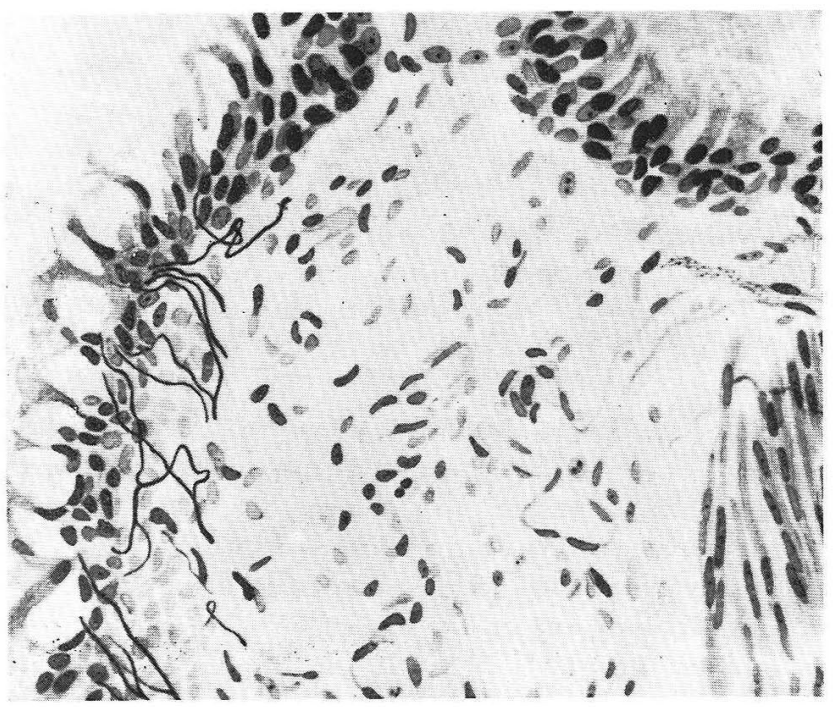

Fig. 10. Many intraepithelial simple branched sensory terminations found in the ciliated epithelium of a large bronchial branch of a Formosan macaque. Details in the text. Same staining. $\times 320$. 
are often complex enough.

In Fig. 10 are found many sensory fibres reaching beneath the epithelium of a large bronchial branch and thence running further into the ciliated epithelium while undergoing more or less ramification, before ending in sharp or blut points. These intraepithelial terminations all originate in medium-sized stem fidres, and accordingly their terminal fibres are comparatively thin and show not much change in size. In Fig. 11 are illustrated a subepithelial and an intraepithelial simple branched terminations found in a bronchial branch $2.5 \mathrm{~mm}$ in diameter. Both are derived from a medium-sized sensory fibre; their 2-3 terminal fibres are fine and devoid of change in size throughout their comparative-ly straight courses and end always sharply.

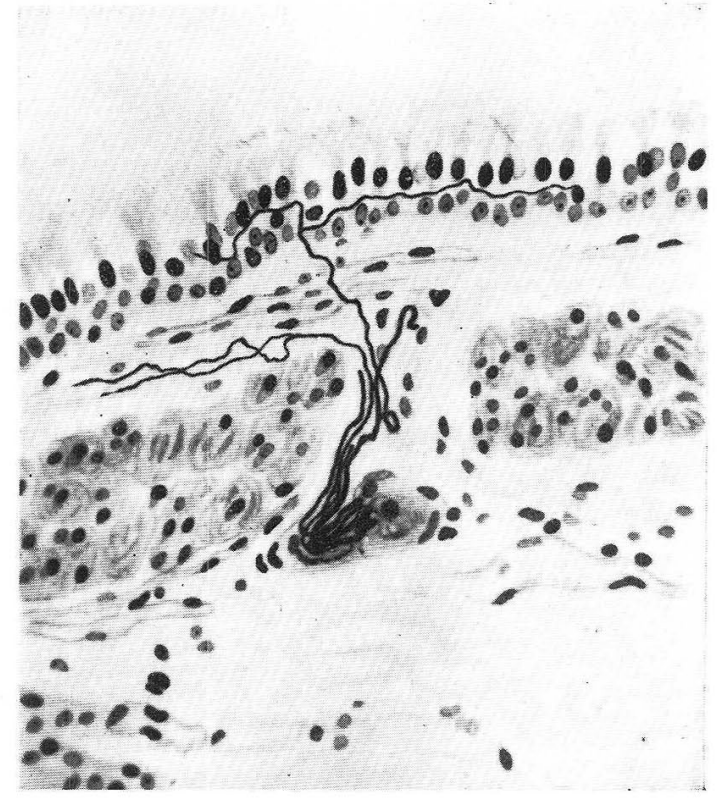

Fig. 11. A subepithelial and an intra epithelial simple branched sensory terminations found in a medium-sized bronchial branch of a Formosan macaque. Details in the text. Same Staining. $\times 320$.

Figs. 12 and 13 show simple branched intraepithelial terminations both originating in very thick sensory fibres, found in a medium-sized bronchial branch. In Fig. 12, we see the thick stem fibre, upon entering the epithelium and decreasing somewhat in size, brauch out into 3 terminal fibres which rather frequently change their size during their more or less winding courses, and end in sharp points. The termination in Fig. 13 is a comparatively complex branched intraepithelial one similarly formed by a thick stem fibre. The $4-5$ terminal fibres are somewhat reduced in size upon entering the epithelium, and showing repeated change in size, end in sharp points.

As shown above, intraepithelial fibres are abundant in the large bronchial 


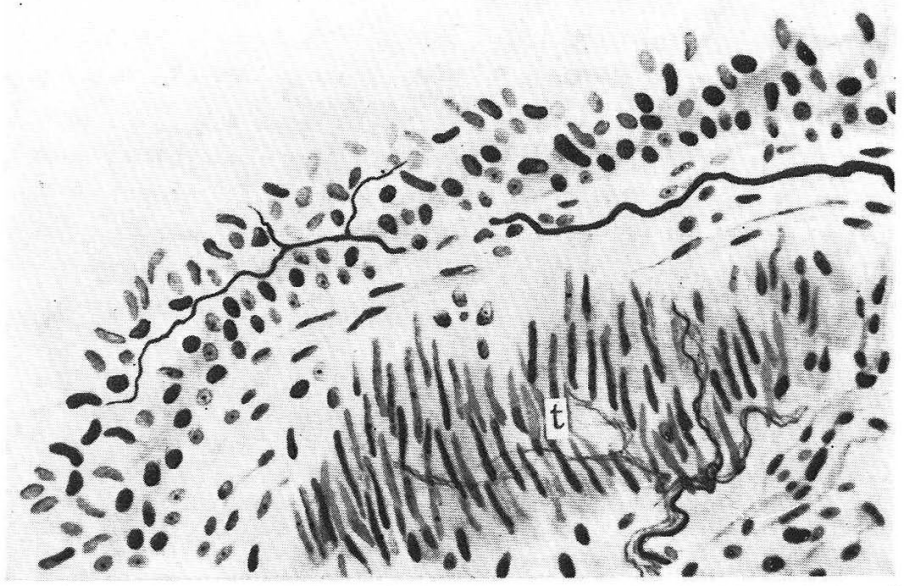

Fig. 12. An intraepithelial simple branched sensory termination originated in a thick nerve fibre found in a medium-sized bronchial branch of a Formosan macaque. Terminal fibres show change in size and end sharply, $t$ vegetative terminal reticulum in the smooth muscle layer. Details in the text. Same staining. $\times 320$.

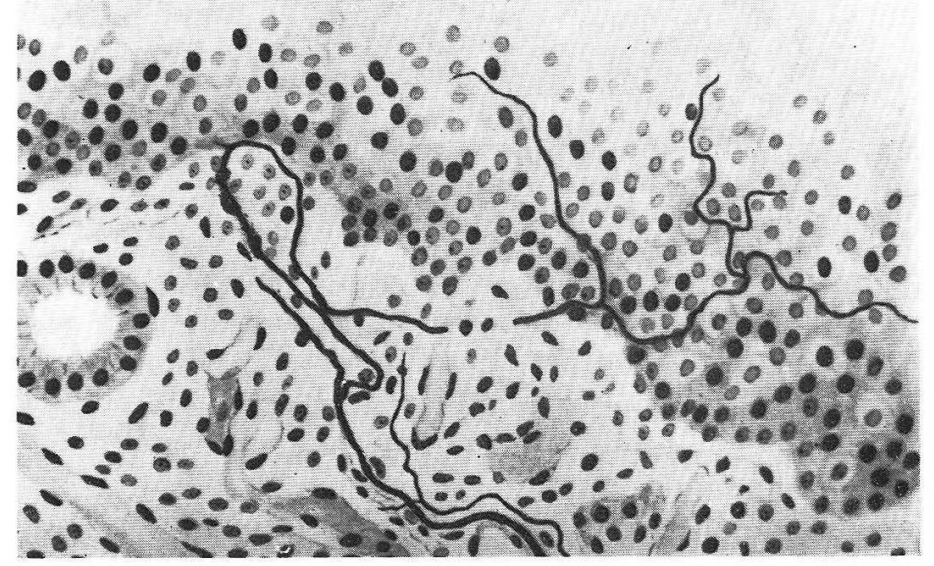

Fig. 13. Ditto. Details in the text. Same staining. $\times 320$.

бгаnches of Formosan macaque. Most of them originate in medium-sized stem fibres and a rather large fart of them end in complex terminations. In the medium-sized bronchial branches, however, intaepithelial terminations are smaller in number and simpler in formation than in the former, but here we note with interest that 
a rather large number of such terminations originating in very thick fibres are found besides those originating in medium-sized stem fibres.

In the small bronchial branches, the number of sensory fibres and their terminations diminishes drastically, but still subepithelial and intraepithelial terminations are not at all rare. Their size and development, however, are much inferior than those observed in the larger bronchial branches.

The bronchioli terminales and rerpiratorii are ratner better provided with sensory fibres and their terminations than the above small bronchial branches. Here, very thick fibres (Fig. 7) are not rare and the terminations often contain rather many branch fibres.

In Fig. 14 is shown a rather complex branched termination originating in a

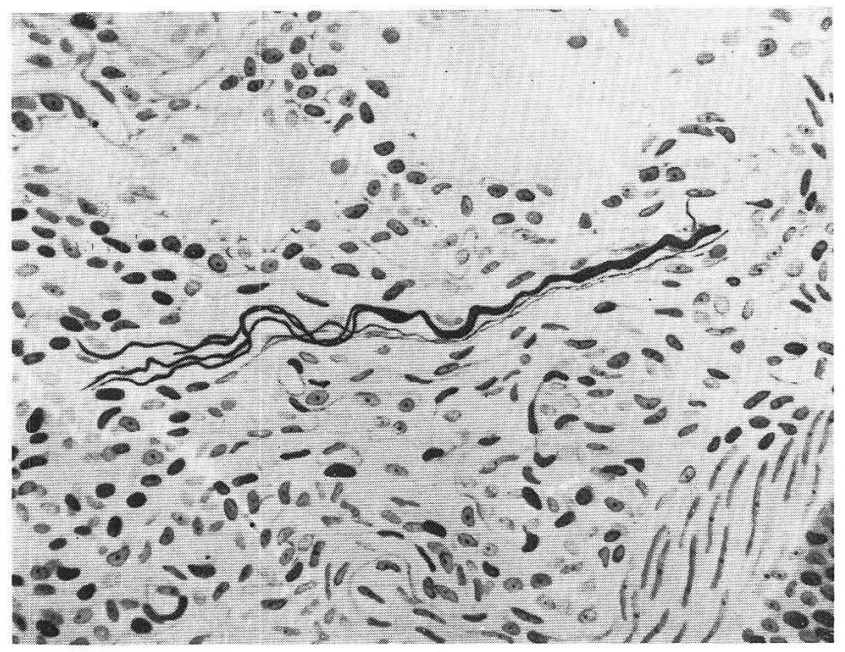

Fig. 14. A rather complex branched termination originated in a very thick sensory fibre found in the vicinity of a bronchiolus respiratorius of a Formosan macaque. Terminal fibres show change in size and end sharply, fine fibres are vegetative fibres. Same staining. $\times 320$.

very thick sensory fibre and consisting of 4 terminal fibres found in the vicinity of a bronchiolus respiratorius. The terminal fibres show some change in size and end in sharp points. In Fig. 15, we see a very thick sensory fibre running along with fine vegetatve fibres send out a long terminal fibre which ends beneath a bronchilus respiratorius. The stem fibre here being cut midways in its course, the subsequent branching cannot be traced.

Besides the above-described branched terminations, not a few unbranched terminations may be found in the bronchial branches and the bronchioli. For example, in Fig. 16 is illustrated an unbranched termination originating in a thick sensory fibre formed in a bronchiolus respiratorius. This fibre shows a rather peculiar winding and some change in size in its course and ends sharply just beneath the epithelium. In Fig. 17 we see an unbranched termination originating in a mediumsized stem fibre and perhaps penetrating into the 1-rowed cubic epithelium of a 


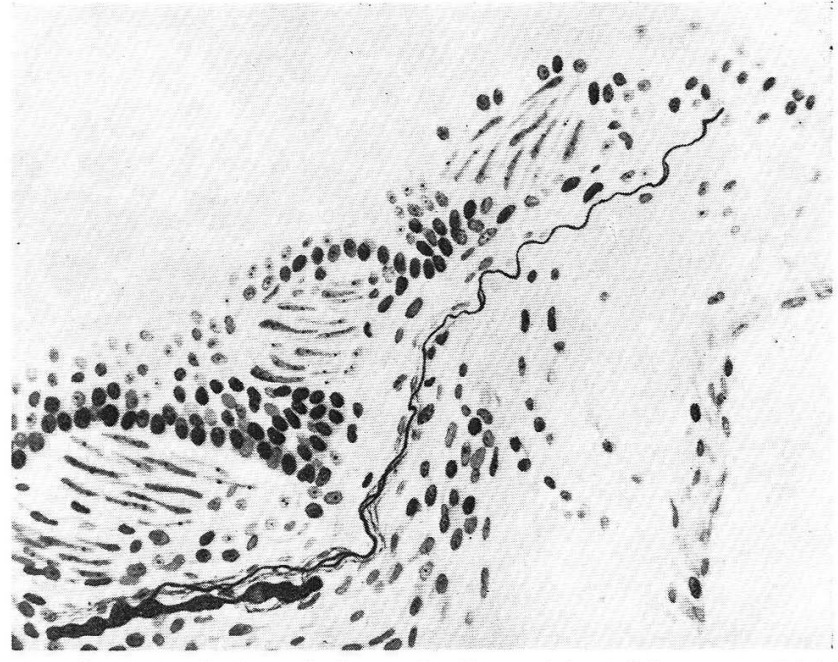

Fig. 15. A simple branched termination originated in a very thick sensory fibre found in the wall of a bronchiolus of a Formosan macaque. A thin terminal fibre runs a long course before ending beneath the epithelium of the bronchiolus, while the thick stem fibre is cut midways in its course. Same staining. $\times 320$.

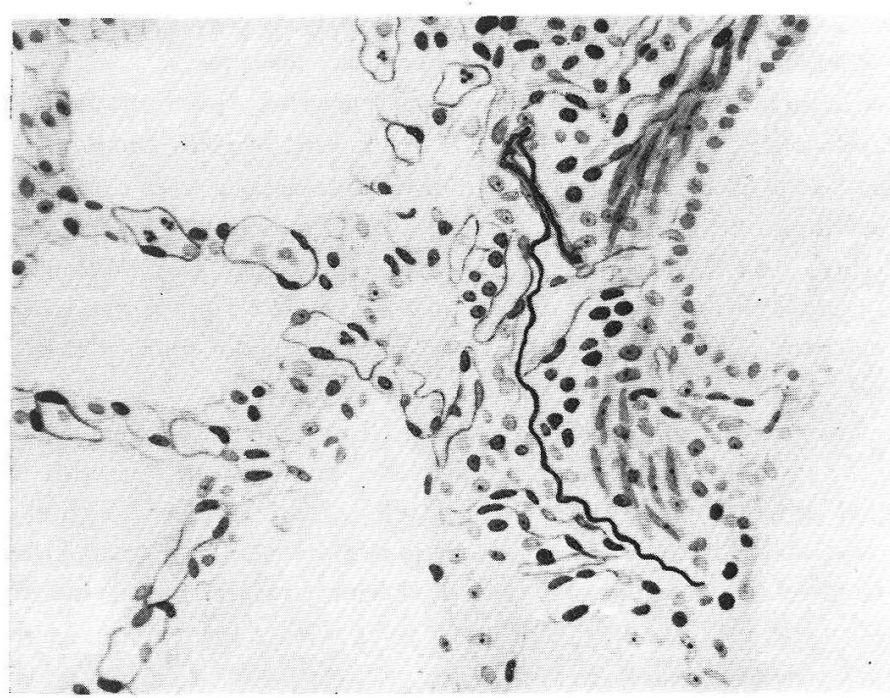

Fig. 16. An unbranched sensory termination originated in a thick fibre formed in a bronchiolus respiratorius of a Formosan macaque. Details in the text. Same staining. $\times 320$.

bronchiolus respiratorius before ending. This fibre shows fibrillar expansions now and then during its course. Thus, it is very interesting that a rather large number of unbranched and branched terminations formed by thick and medium-sized sensory 


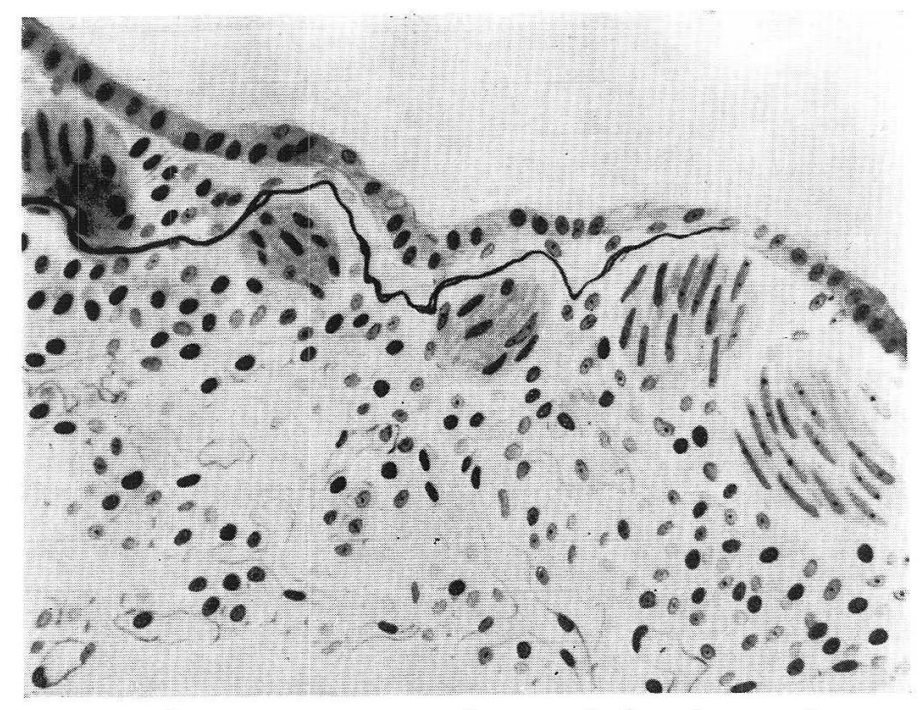

Fig. 17. An_unbranched termination"originated in" a medium-sized sensory fibre and penetrating into the one-rowed cubic epithelium of a bronchiolus respiratorius before ending. Formosan macaque. This sensory fibre shows fibrillar expansions here and there during its course. Same staining. $\times 320$.

fibres are to be found in the bronchioli of Formosan macaque.

It has been made clear that the lung parenchyma also contains well-formed sensory terminations, as found by OMOTO in the lung of goat. Similarly, the lung parenchyma or the alveolar walls of my Formosan macaque were rather rich in unbranched or simple branched sensory terminations mostly originating in mediumsized stem fibres. In Fig. 18 is shown an example of such terminations - a welldefined bifurcated termination of a medium sized sensory fibre formed in close contact with the alveolar epithelium. Its terminal fibres show some change in size in their courses.

In the last place, I must mention that small nerve bundles are very frequently found running in the collagenous connective tissue of the pleura visceralis of Formosan macaque. What is particularly interesting is that these nerve bundles consist always of myelinated sensory fibres alone and contain many very thick fibres. For example, in Fig. 19, the course of a very thick sensory fibre running out of the deep layer of the pleura into its superficial layer along with a few thinner sensory fibres is very clearly discernible.

Such sensory fibres in the pleura, as those in bat (NUMATA), after losing their myelin sheaths, run without branching long winding courses while showing considerable change in size and end in sharp points after reaching superficial layer of the pleura in most cases. In Figs. 20 and 21 are shown typical exampels of such intrapleural fibres, which form such very peculiar unbranched sensory terminations as described above. 
Fig. 18. A bifurcated termination of a medium-sized sensory fibre formed in close contact with the alveolar epithelium in the lung parenchyma of a Formosan macaque. Same staining. $\times 320$.
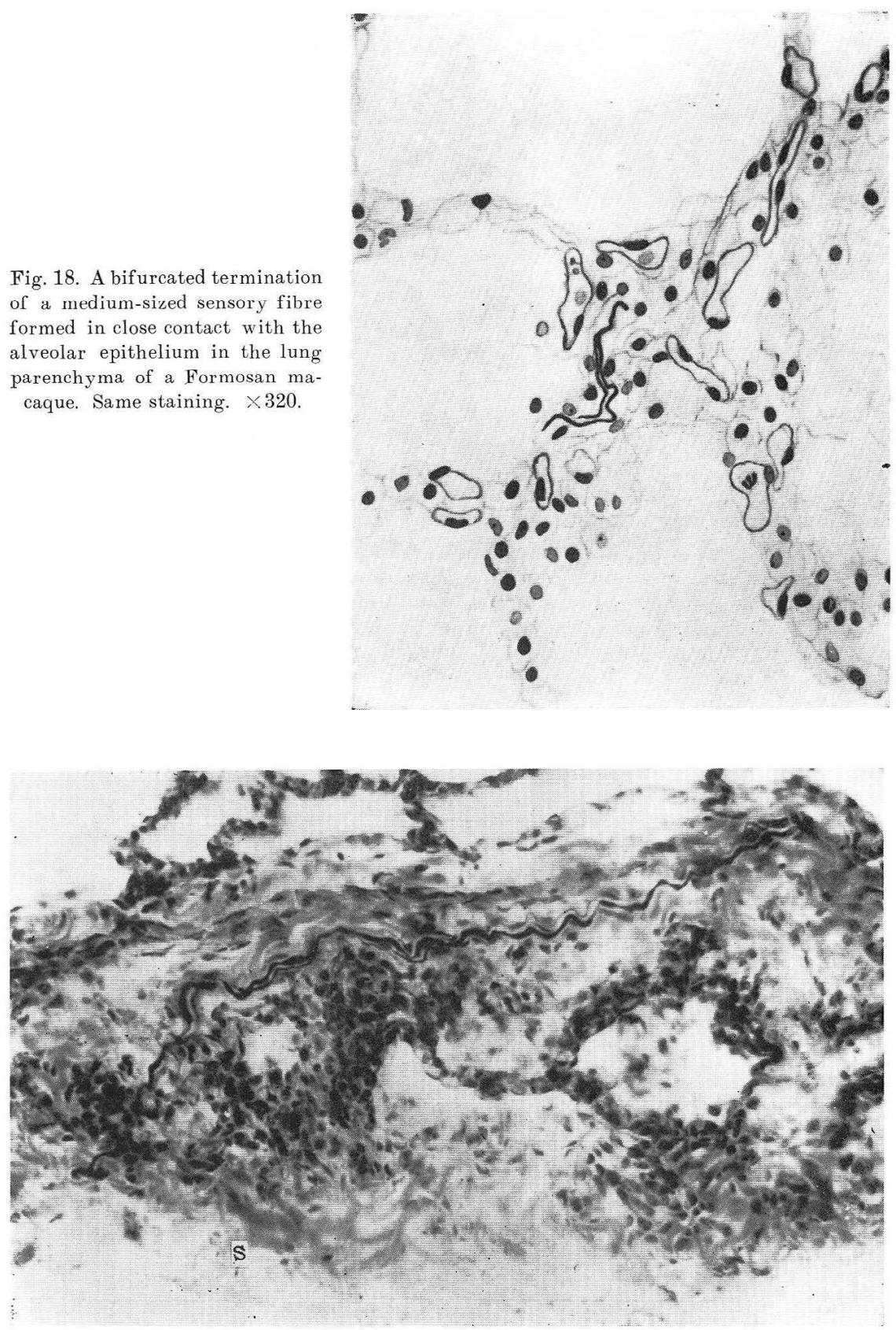

Fig. 19. A very thick sensory fibre running out of the deep layer of the pleura visceralis into its superficial layer $s$ being accompanied with a few thinner sensory fibres. Formsan macaque. Same staining. Photo $\times 200$. 


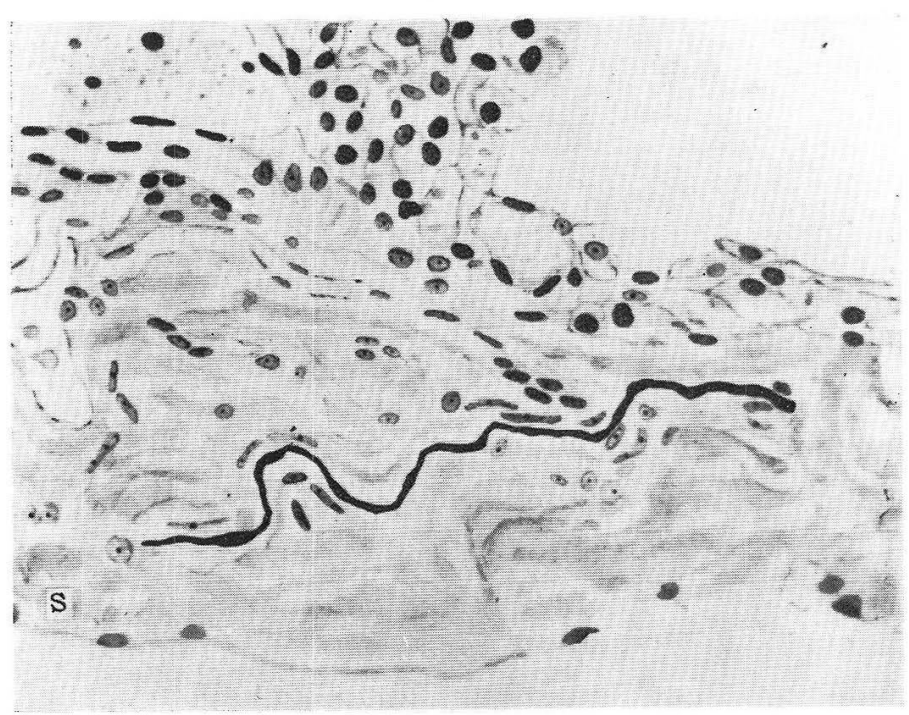

Fig. 20. An unbranched sensory termination showing conspicuous change in size and ending sharply found in the pleura visceralis of a Formosan macaque. $s$ superficial laver of the pleura. Same staining. $\times 320$.

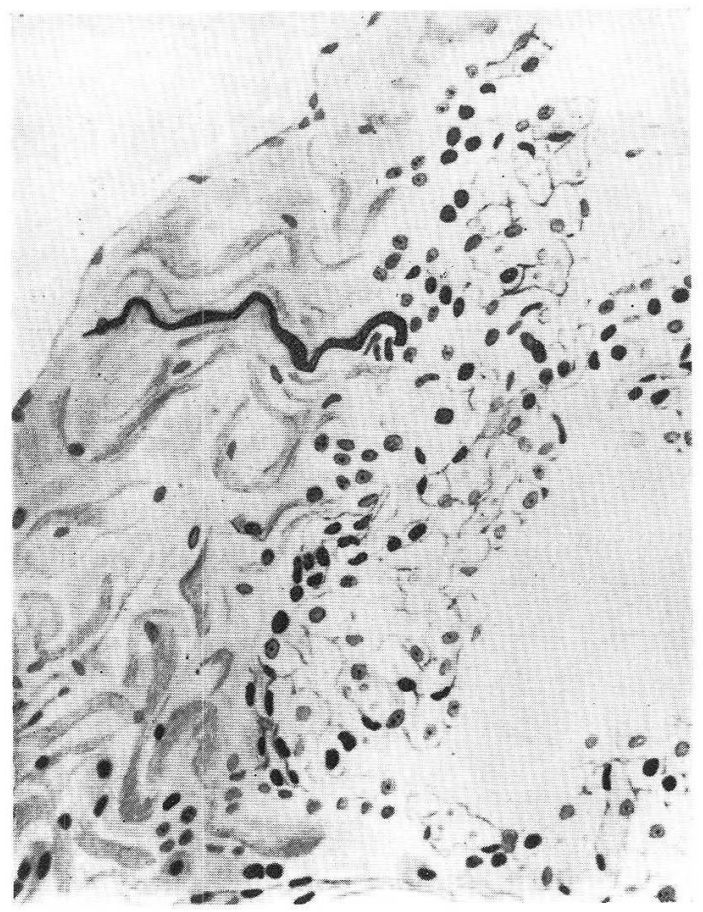

Fig. 21. Ditto. Same staining. $\times 320$. 
Thus, I could blamelessly demonstrate the existence of terminations of sensory fibres in the pleura visceralis of Formosan macaque, as NUMATA has previously done in his bat, and this discovery of such intrapleural terminations may be of value in suggesting the probability of such sensory terminations being found in the pleura visceralis of man and other animals too.

\section{Summary.}

The fundamental nerve plexus formed in the large bronchial branches of Formosan macaque is much worse developed than that in the human lung, the ganglion found therein being very small both in number and in size. The submucosal plexus of course is very poorly developed, especially so in the submucosa lining the inside of the cartilages and containing not many bronchial glands. The poor development of these plexuses further falls even lower as the bronchial branches ramify into smaller and smaller branches.

The nerve plexus found in the intrapulmonary bronchial walls contains a considerable number of medium- and large sized medullated sensory fibres, besides the non-medullated vegetative fibres.

The ganglion cells forming the ganglia are not easily classifiable into DOGIEL's Type I and Type II cells, though it is clear that they belong to the sympathicus for they betray multipolarity by their nerve processes. The vegetative fibres in the bronchial branches, as everywhere else, end in STÖHR's terminal reticula, which are particularly well developed around the bronchial glands and in the muscularis.

More sensory fibres are found in the medium sized than in the large bronchial branches in the lung of Formosan macaque. Of their terminations, mention must be first made of those concerned with the blood pressure falling reflex Type I found in the smooth muscle layer. These terminations are more frequent in the mediumsized bronchial branches with well-developed muscle tissue than in the major branches where the muscle tissue is worse developed. A termination of this type usually originates in an enormously thick fibre and is branched into several thick terminal fibres showing change in size in their courses. Such neurofibrillar expansions, as found in the fibres of terminations of this type in the human lung were absent in my macaque's lung, as in the lungs of dog, goat and bat, as reported hitherto.

Besides the above, unbranched and branched sensory terminations were found beneath and in the epithelium of the bronchial branches. Intraepithelial terminations are here more plentiful than subepithelial terminations and, interestingly enough, are particularly abundant in the large bronchial branches. These terminations usually originate in medium.sized fibres, but not rarely, and particularly frequently in the medium-sized bronchial branches, are formed by thick fibres. These terminations are usually more complex in the large than in the medium-sized bronchial branches. Their terminal fibres show little hange in size and those reaching into the epithelium run mostly in winding courses before ending sharply.

In the small bronchial branches, the sensory fibres and their terminations are much fewer but branched subepithelial and intraepithelial terminations here are not rare at all. In proportions, however, these are smaller than those seen in the 
larger bronchial branches, and unbranched terminations are also observed in some places. It is very interesting that the bronchioli smaller than the small bronchial branches are rather rich in sensory fibres and their terminations than the latter. Moreover, very thick fibres are found in the bronchioli ane sensory terminations are sometimes of rather complex type.

As in goat, unbranched and simple branched sensory terminations of mediumsized fibres are often found also in the alveolar walls of the lung in Formosan macaque. The terminal fibres of these terminations frequnntly show very perceptible change in size.

Small bundles of myelinated sensory fibres are very often found in the pleura visceralis, and the fibres may be sometimes called enormously thick. As the same in bat (NUMATA), these fibres, after losing their myelin sheaths, usually run long widing courses without branching but showing frequent change in size and end in sharp points in the superficial layer of the pleura.

\section{内 容 自 抄.}

台湾猿の肺の大型気管支枝に見られる基礎神経叢は人肺に於けるより屯発達が 遙かに劣勢，又その中に見られる神経節は数も甚だ少く且つ小型である，粘膜下 膜神経叢の発達も甚だ弱く，特に軟骨板に内接する薄い粘膜下膜内で然りである. 之等神経叢は大型気管支枝が分岐によって小型となるに從って愈々劣勢な発達を 示すが, 無髄性植物神経線維の外に可なり多くの中等大及び太い有髄性知覚線維 を含むととは人及び他動物に於けると異ならない，神経節内の神経細胞は交感性 を示すが，Dogiel 氏第 I 型及び II 型細胞の区別は人に於けると異って甚だ困難 である，植物線維の終末はStöhr 氏終網で表わされる。

知覚終末は大型気管支枝に於けるよりも中型のあのに於いてょり多く発見され る。その終末には第 I に筋層内に形成される血圧下降反射に関する知覚終末第 I 型が挙げられる。之は発達の最良好な筋層を所有する中型気管支枝に最も屢々発 見され，そして甚だ太い線維に由来し，太さの変化に富んだ数条の終末枝から成 る分岐性終末で表わされる。但し人肺のもの之異って原線維性拡散小板はこの動 物であ他動物に於けると同様証明されない.

次に気管支枝の上皮下及び上皮肑に非分岐性及び分岐性終末の形成を見る．乙 の両終末の中，上皮内終末は上皮下終末よりあより多量に見られ，且つ大型気管 支枝に於て特に多数発見される事は興味深い，之等綕末は専ら中等大線維に由来 するが, 又霋々太い線維にも由来する，その終末枝は一般に太さの変化を示す事 は少く，上皮内に大ったものは迁りを以て走り專ら尖鋭状に終る.

小型気管支枝では知覚終末の量は急激に減少するが，尚稀ならず上皮下及び上 皮内分岐性終末の形成を見る，但しその規模は甚だ劣勢であり，乙っでは専ら非 分岐型で表わされる。 反之細気管支は小型気管支枝よりも知覚神経要素に富む事 は興味深い，而もここでは極めて太い線維の走行も見られるし，又可なり複難な 
On Nerve Supply, especially, Sensory Nerve Supply of the Lung in Formosan Macaque. 93

分岐性終末む形成される。

この動物の肺胞壁にむ山羊肺に於けると同様, 可なり屢々中等大知覚線維に由 来する非分岐性及び単純性分岐性終末が発見される。その終末枝は太さの変化を 示す事が多い.

内臓胸膜内に甚だ䨢々太い又は甚だ太い知覚線維が小束をなして走り，そして 蝙蝠でもそうである様に，髄鞘を失った後，分岐する事なく，太さの変化と迁り とを示して長い経過の後, 胸膜の表層に尖鋭状に終る.

\section{References.}

Hayashi, S.: Mikroskopische Studien zur Innervation der Lunge. J. orient. Med. 27 (1937). - Larsell a. Dow: The innervation of the human lung. Amer. J. Anat. 52 (1933). - Loffredo, C.: Ricerche istologiche comparative sulle espansioni nervose sensitive della trachea e dei bronchi. Boll. Soc. ital. biol. sperim. 26 (1950). — Numata, T.: Histology and innervation of lung in bat. Arch. hist. jap. 9 (1956). - Omoto, H.: On the nerve supply of trachea, bronchus and lung in goat. Arc h. hist. jap. 15 (1958). - Saito, M.: Supplement to the observations on the innervation of lung in dog. Arch. hist. iap. 9 (1955). - Sasaki, Y.: Microscopic observations on the innervation of human larynx. Tohoku Igaku Zassi. 32 (1943). - Stöhr, Ph.: Möllendorffs Handbuch der mikroskopischen Anatomie des Menschen. Bd. 4. Nervensystem. Tl. 1. J. Springer, 1957. - Sunder-Plass mann, P.: Über nervöse Rezeptorenfelder in der intrapulmonalen Bronchien des Menschen usw. Dtsch. Z. Chir. 240 (1933). - Yagita, M.: A histological study of sensory nerves in the lung and the visceral pleura. Arch. jap. Chir. 23 (1954). 